\title{
PENGETAHUAN IBU DAN CARA PENANGANAN DEMAM
} PADA ANAK

\author{
Dyoko Gumilang Sudibyo, Rila Putri Anindra, Yerlita El Gihart, Risma Alvin Ni'azzah, Nur Kharisma, \\ Sukma Cindra Pratiwi, Safira Dewanti Chelsea, Risca Fernanda Sari, Ima Arista, Va Melisa Damayanti, \\ Ella Wardah ‘Azizah, Ebora Poerwantoro, Hita Fatmaningrum, Andi Hermansyah* \\ Departemen Farmasi Komunitas, Fakultas Farmasi, Universitas Airlangga \\ Gedung Nanizar Zaman Joenoes Kampus C, Jl. Ir. Soekarno, Surabaya 60115, Indonesia \\ E-mail: andi-h@ff.unair.ac.id
}

\begin{abstract}
ABSTRAK
Penanganan demam pada anak tergantung pada peran orangtua, terutama ibu, sehingga diperlukan pengetahuannya dalam menangani demam. Namun, tingkat pengetahuan ibu sangat bervariasi yang mengakibatkan perbedaan pengelolaan demam pada anak. Pengetahuan yang kurang mengakibatkan penanganan yang tidak tepat, sehingga penyembuhan menjadi kurang optimal. urvei ini bertujuan untuk mengidentifikasi pengetahuan ibu mengenai demam pada anak serta cara penanganannya. Penelitian ini merupakan survei cross sectional dengan menggunakan instrumen kuesioner elektronik. Responden adalah $130 \mathrm{ibu}$ yang memiliki anak usia 0-12 tahun di Kelurahan Wonokusumo, Surabaya dengan teknik accidental sampling. Data diolah secara deskriptif. Banyak ditemukan penggunaan antipiretik yang cenderung berlebihan bahkan diberikan walau suhu tubuh belum tergolong demam. Kemudian, lebih dari $50 \%$ responden mengukur demam dengan meraba bagian tubuh dan tidak menggunakan termometer. Hampir 50\% responden langsung memberikan obat antipiretik pada anaknya tanpa pemberian pertolongan nonfarmakologi terlebih dahulu, walaupun sebagian dari responden tidak mengetahui efek samping dari obat antipiretik. Antipiretik yang paling sering digunakan adalah parasetamol. Sumber informasi penggunaan antipiretik terbanyak dari resep sebelumnya. Sebagian responden belum mengetahui cara mengenali demam dan penanganan demam secara farmakologi dan nonfarmakologi. Responden sering melakukan swamedikasi dengan penggunaan parasetamol karena mudah didapatkan dan harganya pun terjangkau, meskipun mereka belum mengetahui efek sampingnya.
\end{abstract}

Kata kunci: pengetahuan ibu, demam anak, antipiretik, efek samping, Surabaya

\begin{abstract}
Parents, especially mother, holds a very important role in managing treatment for fever in children. Unfortunately, mother's knowledge about fever is still low and it could lead to ineffective treatment. This study was conducted to identify mother's knowledge about fever and the right treatment. This was a cross sectional study consisted of 130 mothers with children 0-12 years of age. Sample was recruited by accidental sampling method and data were collected using an electronic questionnaire performed in googleform. This study showed that antipyretic drugs were still highly overused without knowing the adverse effect of the drugs. More than $50 \%$ of the respondents were still using the conventional way to check their children's body temperature by touching their forehead or another part of the body without thermometer. Mostly used antipyretic was paracetamol and they chose this medication based on their previous experience. Less information and knowledge about fever towards the parents, especially mother, will decrease effectivity of the treatment.
\end{abstract}

Keywords: mother's knowledge, fever in children, antipyretic drugs, adverse effects, Surabaya 


\section{PENDAHULUAN}

Demam adalah kondisi dimana suhu tubuh berada di atas normal (Wardiyah et al., 2015). Suhu tubuh normal manusia berkisar pada 36$37^{\circ} \mathrm{C}$, namun saat demam dapat melebihi $37^{\circ} \mathrm{C}$ (Kurniati, 2016). Demam antara lain disebabkan karena infeksi atau adanya ketidakseimbangan antara produksi panas dan pengeluarannya (Salgado et al., 2016). Meskipun demikian, demam berperan dalam meningkatkan perkembangan imunitas spesifik dan nonspesifik dalam membantu pemulihan, pertahanan terhadap infeksi dan sinyal bahwa tubuh sedang mengalami gangguan kesehatan (Wardiyah et al., 2015).

Demam merupakan salah satu tanda penyakit yang paling umum. Demam menjadi alasan di balik $15-25 \%$ kunjungan pasien di fasilitas pelayanan kesehatan dasar atau unit gawat darurat (Barbi et al., 2017). Di Indonesia, sebanyak 30\% kunjungan ke dokter anak disebabkan oleh demam (IDAI, 2014). Meskipun pada beberapa kasus demam dapat ditangani tanpa intervensi medis, demam tinggi dapat mengakibatkan kejang demam. Kejang demam adalah kejang yang terjadi pada kenaikan suhu tubuh $38^{\circ} \mathrm{C}$ atau lebih yang disebabkan oleh proses di luar otak. Sebagian besar kejang demam terjadi pada anak usia 6 bulan sampai 5 tahun. Ciri khas kejang demam adalah demamnya mendahului kejang. Pada saat kejang, anak masih demam dan setelah kejang, anak langsung sadar kembali (IDAI, 2014).

Penanganan demam terbagi menjadi dua, yaitu penanganan tanpa obat (terapi nonfarmakologis) dan dengan obat (terapi farmakologis). Penanganan tanpa obat dilakukan dengan pemberian perlakuan khusus yang dapat membantu menurunkan suhu tubuh meliputi pemberian cairan, penggunaan kompres, dan menghindari penggunaan pakaian terlalu tebal (Kristiyaningsih et al., 2019). Penanganan dengan obat dilakukan dengan pemberian obat golongan antipiretik yang dapat menurunkan suhu tubuh dengan berbagai mekanisme (Lubis et al., 2016).

Pemilihan obat yang tepat dapat membantu menurunkan demam pada anak. Kebanyakan ibu lebih memilih melakukan swamedikasi dengan obat yang pernah diresepkan oleh dokter sebelumnya. Parasetamol merupakan obat yang paling sering digunakan untuk mengatasi demam (antipiretik) pada anak (Surya et al., 2018). Antipiretik lainnya adalah ibuprofen dan aspirin. Namun, pemberian aspirin tidak direkomendasikan sebagai pilihan pertama karena dikaitkan dengan Sindrom Reye, yaitu suatu kondisi yang jarang terjadi namun berbahaya bagi liver dan otak (Sari et al., 2018).

Antipiretik sangat mudah didapatkan secara bebas baik di apotek, supermarket, hingga toko kelontong. Sayangnya, ketika masyarakat membeli obat di luar apotek, masyarakat tidak mendapatkan informasi yang lengkap mengenai obat tersebut. Tidak adanya informasi penting misalnya tentang aturan pakai obat, dosis, serta efek samping dapat menim-bulkan efek yang buruk kepada pasien. Parasetamol dapat menimbulkan reaksi alergi pada kulit dan bisa menyebabkan gangguan pada liver jika digunakan jangka panjang (Bebenista et al., 2014). Selain itu, parasetamol seharusnya diberikan ketika suhu tubuh $>39^{\circ} \mathrm{C}$. Namun pada penerapannya, sering kali parasetamol diberikan ketika suhu tubuh masih $<38^{\circ} \mathrm{C}$ (Surya et al., 2018).

Kejadian demam pada anak dapat menimbulkan kecemasan pada orangtua yang disebut dengan fobia demam (Fuadi, 2010; Soedibyo, 2006). Hasil penelitian menunjukkan hampir $80 \%$ orangtua mempunyai fobia demam (Kristiyaningsih et al., 2019). Orangtua yang cemas berusaha untuk menormalkan suhu tubuh anak kembali. Alhasil, meskipun suhu tubuh anak $<38^{\circ} \mathrm{C}$, sebagian orangtua langsung memberikan antipiretik meskipun gejala sang anak masih termasuk demam ringan (Surya et al., 2018). Fobia demam juga menyebabkan $85 \%$ orangtua $(\mathrm{n}=340)$ membangunkan anaknya dari tidur mereka untuk diberi antipiretik (Sullivan et al., 2011). Fobia demam sering ditemui pada ibu dengan tingkat ekonomi tinggi yang baru memiliki satu anak (Gunduz et al., 2016).

Penanganan demam pada anak sangat tergantung pada peran orangtua, terutama ibu. Dari berbagai penelitian yang dilakukan di Indonesia, diketahui bahwa tingkat pengetahuan ibu tentang penanganan demam pada anak sangat bervariasi. Perbedaan tingkat pengetahuan ini mengakibatkan perbedaan pengelolaan demam pada anak. Ditambah dengan kemudahan untuk membeli antipiretik secara bebas dan peran ibu yang vital dalam kesehatan keluarga, penanganan demam pada anak oleh ibu menjadi hal yang penting untuk diteliti. Pengetahuan yang kurang dapat mengakibatkan penanganan yang tidak tepat sehingga membuat kesehatan anak menjadi lebih berisiko (Riandita, 2012).

Menurut Jayarni dan Sumarmi (2018), sebagian besar ibu yang memiliki balita di daerah Kelurahan Wonokusumo merupakan tamatan SD/sederajat dan tidak bekerja, dengan pendapatan keluarga kurang dari rata-rata 
masyarakat Surabaya. Fakta lainnya, rata-rata ibu di Kelurahan Wonokusumo menikah pada usia muda, sebuah faktor yang turut mempengaruhi pengelolaan kesehatan keluarga. Oleh karena itu, penelitian ini bertujuan untuk mengidentifikasi persepsi ibu di Kelurahan Wonokusumo tentang demam pada anak dan cara penanganannya.

\section{METODE}

Penelitian observasional dilakukan untuk mengetahui persepsi ibu tentang demam dan tindakan penanganan demam pada anak di daerah Wonokusumo, Surabaya. Teknik sampling yang digunakan adalah accidental sampling dengan kriteria inklusi sampel adalah ibu yang memiliki anak dengan rentang usia 0 hingga 12 tahun di daerah Wonokusumo dan kriteria eksklusi meliputi ibu dengan anak yang berusia lebih dari 12 tahun.

Instrumen yang digunakan adalah kuesioner tipe kombinasi pertanyaan tertutup dan terbuka. Kuesioner disusun dengan adopsi dan modifikasi dari penelitian sebelumnya, yaitu penelitian oleh Mufaza pada tahun 2009. Pertanyaan dalam kuesioner meliputi tiga bagian yaitu (1) pertanyaan tentang karakteristik dan aspek demografis responden sejumlah 11 pertanyaan, (2) pengetahuan ibu tentang demam pada anak sejumlah 10 pertanyaan, dan (3) tindakan yang dilakukan ibu untuk mengatasi demam pada anak sejumlah 7 pertanyaan. Kuesioner dibuat secara elektronik menggunakan Google form ${ }^{\circledR}$ dengan metode pengisian yang dilakukan adalah interviewer assisted administration untuk memudahkan responden menjawab pertanyaan.

Proses pengambilan data dilakukan secara cross sectional pada 11 September 2019. Data yang diperoleh kemudian diolah menggunakan Microsoft Excel $^{\circledR}$ dan disajikan dalam bentuk tabulasi hasil.

\section{HASIL DAN PEMBAHASAN}

Sebanyak 130 responden berpartisipasi dalam survei ini. Dari 130 responden, sebanyak $5,4 \%$ berusia di bawah 20 tahun, 35,4\% berusia 21-30 tahun, sebanyak 36,9\% berusia 31-40 tahun, $16,9 \%$ berusia $41-50$ tahun, dan sisanya berusia di atas 50 tahun. Pendidikan terakhir responden yang paling banyak adalah SMA $(32,3 \%)$ dan yang paling sedikit adalah lulusan D1/D2/D3/D4 (3,1\%). Mayoritas responden adalah ibu rumah tangga $(76,2 \%)$, sementara sisanya bekerja sebagai wirausahawan $(23,8 \%)$.
Tabel 1. Karakteristik Demografi Responden $(\mathrm{n}=$ 130)

\begin{tabular}{|c|c|c|c|}
\hline No & Karakteristik & Jumlah & Persentase \\
\hline \multirow[t]{6}{*}{1} & Usia & & \\
\hline & $<20$ tahun & 7 & $5,4 \%$ \\
\hline & 21-30 tahun & 46 & $35,4 \%$ \\
\hline & $31-40$ tahun & 48 & $36,9 \%$ \\
\hline & 41-50 tahun & 22 & $16,9 \%$ \\
\hline & $>50$ tahun & 7 & $5,4 \%$ \\
\hline \multirow[t]{7}{*}{2} & $\begin{array}{l}\text { Pendidikan } \\
\text { terakhir }\end{array}$ & & \\
\hline & Tidak sekolah & 7 & $5,4 \%$ \\
\hline & Tamat SD & 37 & $28,5 \%$ \\
\hline & Tamat SMP & 37 & $28,5 \%$ \\
\hline & $\begin{array}{c}\text { Tamat SMA } \\
\text { Tamat }\end{array}$ & 42 & $32,3 \%$ \\
\hline & $\begin{array}{c}\text { D1/D2/D3/D4 } \\
\text { Tamat }\end{array}$ & 4 & $3,1 \%$ \\
\hline & $\mathrm{S} 1 / \mathrm{S} 2 / \mathrm{S} 3$ & 3 & $2,3 \%$ \\
\hline \multirow[t]{3}{*}{3} & Pekerjaan & & \\
\hline & $\begin{array}{c}\text { Ibu Rumah } \\
\text { Tangga }\end{array}$ & 99 & $76,2 \%$ \\
\hline & Wirausaha & 31 & $23,8 \%$ \\
\hline
\end{tabular}

Sebanyak $13 \%$ responden menjawab tidak mengetahui penyebab demam pada anak. Meskipun persentasenya kecil, temuan ini menarik untuk dicermati karena berpotensi mengakibatkan kegagalan dalam mengidentifikasi penyebab demam. Demam adalah mekanisme tubuh yang menguntungkan dalam memerangi infeksi dan bukanlah suatu penyakit, namun mengetahui penyebab demam merupakan hal yang penting dalam penegakan diagnosis. Kurangnya pengetahuan tentang demam dapat memunculkan rasa cemas yang berlebihan pada orangtua dan akan menimbulkan fobia demam. Hal ini akan mendorong orangtua untuk memberikan obat antipiretik meskipun anak mengalami demam ringan atau tidak demam (Sullivan et al., 2011).

Sebanyak $61,5 \%$ responden meraba tubuh anak untuk mengenali kondisi demam pada anak. Kepala dan leher merupakan bagian tubuh yang paling sering diraba untuk mengidentifikasi demam. Identifikasi demam dengan cara meraba anak sebenarnya kurang tepat karena suhu tubuh tidak dapat diketahui secara akurat. Di lain pihak, hanya sekitar $30,8 \%$ responden yang menggunakan termometer dalam mengidentifikasi demam pada anak. Nilai ini menunjukkan bahwa belum banyak masyarakat yang menggunakan termometer. Dari hasil survei diketahui bahwa 97,5\% responden yang memiliki termometer memilih menggunakan termometer di ketiak anak.

Manifestasi demam pada prinsipnya dapat diukur dari beberapa bagian tubuh antara lain aksila (ketiak), rektum, mulut, kulit, dan telinga. Suhu oral dan rektum dianggap sebagai tempat 
paling akurat untuk mengukur suhu tubuh, khususnya untuk anak-anak di bawah tiga tahun (Wyckoff, 2009). Namun, penggunaannya tidak disarankan karena menimbulkan rasa tidak nyaman, sehingga alternatif yang dipilih adalah mengukur suhu aksila atau ketiak (Barbi et al., 2017).

Tabel 2. Karakteristik Demografi Anak Responden (n

\begin{tabular}{|c|c|c|c|}
\hline No & Karakteristik & Jumlah & Persentase \\
\hline \multirow[t]{7}{*}{1} & Jumlah Anak & & \\
\hline & 1 & 40 & $30,8 \%$ \\
\hline & 2 & 36 & $27,7 \%$ \\
\hline & 3 & 30 & $23,1 \%$ \\
\hline & 4 & 11 & $8,5 \%$ \\
\hline & 5 & 7 & $5,4 \%$ \\
\hline & 6 & 6 & $4,6 \%$ \\
\hline \multirow[t]{9}{*}{2} & Rentang Usia & & \\
\hline & Anak & 27 & $20,8 \%$ \\
\hline & $<1$ tahun & 33 & $25,4 \%$ \\
\hline & 1-2 tahun & 20 & $15,4 \%$ \\
\hline & 3-4 tahun & 15 & $11,5 \%$ \\
\hline & $5-6$ tahun & 16 & $12,3 \%$ \\
\hline & $7-8$ tahun & 9 & $6,9 \%$ \\
\hline & $9-10$ tahun & 10 & $7,7 \%$ \\
\hline & 11-12 tahun & & \\
\hline \multirow[t]{4}{*}{3} & Jenis Kelamin & & \\
\hline & Anak & 55 & $42,3 \%$ \\
\hline & Laki-laki & 75 & $57,7 \%$ \\
\hline & Perempuan & & \\
\hline \multirow[t]{6}{*}{4} & Pendidikan Anak & & \\
\hline & Belum sekolah & 74 & $56,9 \%$ \\
\hline & $\begin{array}{c}\text { Kelompok } \\
\text { bermain }\end{array}$ & 9 & $6,9 \%$ \\
\hline & (KB/PAUD) & 12 & $9,2 \%$ \\
\hline & TK & 35 & $26,9 \%$ \\
\hline & SD & & \\
\hline
\end{tabular}

Tabel 3. Karakteristik Klinis Anak Responden

\begin{tabular}{|c|c|c|c|}
\hline No & Karakteristik & Jumlah & Persentase \\
\hline 1 & $\begin{array}{l}\text { ASI untuk Anak } \\
\text { di bawah } 2 \text { Tahun } \\
(\mathrm{n}=60) \\
\text { Ya } \\
\text { Tidak }\end{array}$ & $\begin{array}{l}20 \\
40\end{array}$ & $\begin{array}{l}33,3 \% \\
66,7 \%\end{array}$ \\
\hline 2 & $\begin{array}{l}\text { Imunisasi dalam } 1 \\
\text { Minggu Terakhir } \\
(\mathrm{n}=130) \\
\text { Tidak imunisasi } \\
\text { Polio } \\
\text { BCG } \\
\text { DPT } \\
\text { Campak } \\
\text { Hepatitis B } \\
\text { Imunisasi lainnya }\end{array}$ & $\begin{array}{c}106 \\
4 \\
1 \\
1 \\
1 \\
1 \\
16\end{array}$ & $\begin{array}{c}81,5 \% \\
3,1 \% \\
0,8 \% \\
0,8 \% \\
0,8 \% \\
0,8 \% \\
12,3 \%\end{array}$ \\
\hline 3 & $\begin{array}{c}\text { Penyakit Anak } \\
\text { dalam } 2 \text { Minggu } \\
\text { Terakhir }(\mathrm{n}=130) \\
\text { Diare } \\
\text { Batuk } \\
\text { Pilek } \\
\text { Gangguan tidur }\end{array}$ & $\begin{array}{c}19 \\
44 \\
53 \\
1 \\
1\end{array}$ & $\begin{array}{c}15,9 \% \\
36,9 \% \\
44,5 \% \\
0,8 \% \\
0,8 \%\end{array}$ \\
\hline
\end{tabular}

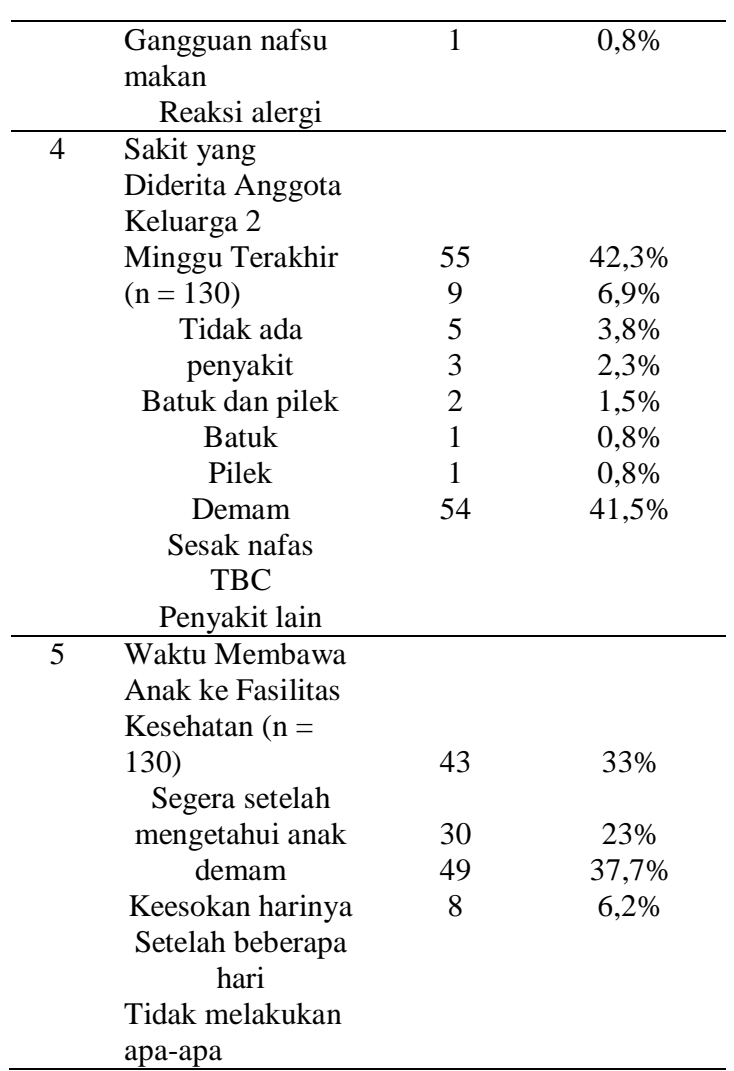

Saat anak terserang demam, terdapat beberapa cara penanganan yang dapat dilakukan. Berdasarkan hasil penelitian, penanganan demam pada anak dengan persentase terbesar kedua di Wonokusumo adalah dengan mengompres anak. Sebanyak 52\% responden mengompres anaknya dengan kompres hangat sedangkan 22\% mengompres dengan air dingin dan $26 \%$ dengan air biasa. Tindakan responden dengan menggunakan kompres hangat sudah sesuai dengan hasil penelitian oleh Masruroh et al., yang dilakukan pada 2017, diketahui bahwa terjadi penurunan suhu tubuh anak yang demam sesudah diberikan kompres hangat di aksila rata-rata $36,5^{\circ} \mathrm{C}$ (Masruroh et al., 2014). Sebanyak 36\% responden memilih melakukan kompres pada daerah ketiak atau aksila dan sebanyak $58 \%$ responden melakukannya di dahi. Berdasarkan penelitian, kompres hangat di daerah ketiak lebih efektif dalam menurunkan suhu tubuh dibandingkan dengan pemberian kompres hangat pada dahi (Ayu et al., 2015). Selain memberikan pertolongan pertama dengan kompres, 20\% responden memilih untuk langsung membawa anak ke dokter, 40,8\% responden memberikan obat penurun panas dan $0,8 \%$ responden memutuskan untuk tidak melakukan apa-apa. Penanganan demam yang disebabkan oleh virus berbeda dengan yang disebabkan oleh bakteri, sehingga dokter harus mengerti patofisiologi demam tersebut sebelum 
memberikan tata laksana. Tetapi seorang dokter juga harus memberikan tata laksana sedini mungkin ketika mendapati demam tinggi pada anak, karena akan berbahaya jika tidak segera ditangani (Mutma'inah, 2019).

Tabel 4. Karakteristik terkait Demam

\begin{tabular}{|c|c|c|c|}
\hline No & Karakteristik & Jumlah & Persentase \\
\hline \multirow[t]{7}{*}{1} & Waktu Terakhir & & \\
\hline & Anak Menderita & & \\
\hline & $\operatorname{Demam}(\mathrm{n}=130)$ & & \\
\hline & $<1$ minggu & 32 & $24,6 \%$ \\
\hline & 1-2 minggu & 27 & $20,8 \%$ \\
\hline & 2-4 minggu & 8 & $6,2 \%$ \\
\hline & $>4$ minggu & 63 & $48,5 \%$ \\
\hline \multirow[t]{10}{*}{2} & Penyebab Demam (n & & \\
\hline & $=130)$ & 59 & $45,4 \%$ \\
\hline & Kelelahan/capek & 8 & $6,2 \%$ \\
\hline & Kurang & 6 & $4,6 \%$ \\
\hline & makan/minum & 3 & $2,3 \%$ \\
\hline & Imunisasi & 19 & $14,6 \%$ \\
\hline & Perubahan cuaca & 18 & $13,8 \%$ \\
\hline & Penyakit lain & 17 & $13 \%$ \\
\hline & Makanan/minuman & & \\
\hline & Tidak tahu & & \\
\hline \multirow[t]{6}{*}{3} & Cara Mengukur & & \\
\hline & $\operatorname{Demam}(\mathrm{n}=130)$ & & \\
\hline & Termometer & 40 & $30,8 \%$ \\
\hline & Meraba bagian tubuh & 80 & $61,5 \%$ \\
\hline & Lain-lain & 7 & $5,4 \%$ \\
\hline & Tidak tahu & 3 & $2,3 \%$ \\
\hline \multirow[t]{5}{*}{4} & Tempat & & \\
\hline & Menggunakan & & \\
\hline & Termometer $(n=40)$ & 1 & $2,5 \%$ \\
\hline & Di bawah & & \\
\hline & $\begin{array}{c}\text { mulut/bawah ketiak } \\
\text { Di ketiak }\end{array}$ & 39 & $97,5 \%$ \\
\hline \multirow[t]{10}{*}{5} & Penanganan Pertama & & \\
\hline & pada Anak Demam & & \\
\hline & $(\mathrm{n}=130)$ & 50 & $38,5 \%$ \\
\hline & Mengompres & 26 & $20 \%$ \\
\hline & Langsung membawa & & \\
\hline & ke dokter & 53 & $40,8 \%$ \\
\hline & Memberi obat & 1 & $0,8 \%$ \\
\hline & penurun panas & & \\
\hline & Tidak melakukan & & \\
\hline & apa-apa & & \\
\hline \multirow[t]{5}{*}{6} & Jenis Kompres yang & & \\
\hline & Digunakan $(n=50)$ & & \\
\hline & Kompres hangat & 26 & $52 \%$ \\
\hline & Kompres dingin & 11 & $22 \%$ \\
\hline & Kompres air biasa & 13 & $26 \%$ \\
\hline \multirow[t]{7}{*}{7} & Tempat Meletakkan & & \\
\hline & Kompres $(\mathrm{n}=50)$ & & \\
\hline & Di dahi & 29 & $58 \%$ \\
\hline & Di ketiak & 18 & $36 \%$ \\
\hline & Di lipatan & 1 & $2 \%$ \\
\hline & Di perut & 1 & $2 \%$ \\
\hline & Di pangkal paha & 1 & $2 \%$ \\
\hline \multirow[t]{3}{*}{8} & $\begin{array}{l}\text { Bahaya Demam Bila } \\
\text { Tidak Segera }\end{array}$ & & \\
\hline & Ditangani $(\mathrm{n}=130)$ & 96 & $73,8 \%$ \\
\hline & Kejang & 1 & $0,8 \%$ \\
\hline
\end{tabular}

\begin{tabular}{ccc}
\hline Kematian & 11 & $8,5 \%$ \\
Dehidrasi & 17 & $13 \%$ \\
Pusing & 5 & $3.8 \%$ \\
Hilang kesadaran & & \\
\hline
\end{tabular}

Pemberian antipiretik pada anak sering dilakukan sendiri oleh orangtua. Fobia terhadap demam sering kali menjadi sebab pemberian antipiretik oleh orangtua sebagai upaya penanganan pertama demam anak. Berdasarkan penelitian yang dilakukan di Kelurahan Wonokusumo, dari 130 responden, sebesar $40,8 \%$ orangtua memberikan obat antipiretik sebagai upaya penanganan pertama mengatasi demam pada anak, baik digunakan sebagai upaya tunggal maupun disertai dengan penggunaan kompres.

Berdasarkan penelitian yang telah dilakukan di Kelurahan Wonokusumo, sebesar 22,3\% responden memberikan antipiretik pada saat suhu tubuh $>39^{\circ} \mathrm{C}$ dan $77,7 \%$ memberikan antipiretik pada suhu tubuh $<39^{\circ} \mathrm{C}$. Hal ini sesuai dengan penelitian Crocetti yang menyatakan bahwa orangtua tidak mengetahui batasan demam pada anak untuk menggunakan antipiretik sehingga cenderung menggunakan antipiretik berlebihan.

Jenis obat demam yang banyak digunakan oleh responden yaitu parasetamol dengan persentase sebesar $77,7 \%$, kemudian ibuprofen $10,8 \%$, dan aspirin 11,5\%. Parasetamol merupakan obat bebas, sehingga tidak dibatasi jumlah penjualannya. Parasetamol banyak digunakan dan relatif mudah didapatkan di toko obat maupun apotek. Hal ini sesuai dengan penelitian yang dilakukan oleh Aqeel pada tahun 2014, yang menyebutkan bahwa golongan obat analgesik banyak digunakan dalam swamedikasi khususnya parasetamol sebesar 42,8\% (Aqeel, 2014). Hal ini diperkuat oleh hasil penelitian oleh Surya et al., pada 2018 dimana 34 dari 50 responden memilih parasetamol untuk menurunkan panas pada anak (Surya et al., 2018).

Sebanyak $77,7 \%$ responden mem-berikan obat antipiretik 3-4 kali sehari untuk anak yang terserang demam. Hal ini sesuai dengan literatur, dimana disebutkan bahwa pemberian parasetamol dengan dosis aman $\leq 5$ kali sehari (Bebenista et al., 2014). Sehingga, dapat disimpulkan responden di daerah Wonokusumo mengetahui aturan penggunaan antipiretik yang tepat sebanyak 3-4 kali sehari.

Berdasarkan data dalam penelitian ini sebanyak $90 \%$ responden tidak mengetahui efek samping dari obat antipiretik dan hanya 10\% saja yang mengetahuinya. Penelitian sebelumnya menunjukkan parasetamol bersifat 
hepatotoksik jika dikonsumsi dalam jangka panjang (Hay et al., 2006). Sementara untuk Ibuprofen dan Aspirin dapat menyebabkan perdarahan pada saluran cerna dan dapat memperburuk kondisi maag penderita (Sostres et al., 2013).

Tabel 5. Karakteristik terkait Antipiretik $(n=130)$

\begin{tabular}{|c|c|c|c|}
\hline No & Karakteristik & Jumlah & Persentase \\
\hline \multirow[t]{7}{*}{1} & Suhu Pemberian & & \\
\hline & Antipiretik & & \\
\hline & $<36^{\circ} \mathrm{C}$ & 9 & $6,9 \%$ \\
\hline & $36-37^{\circ} \mathrm{C}$ & 11 & $8,5 \%$ \\
\hline & $37-38^{\circ} \mathrm{C}$ & 33 & $25,4 \%$ \\
\hline & $38-39^{\circ} \mathrm{C}$ & 48 & $36,9 \%$ \\
\hline & $>39^{\circ} \mathrm{C}$ & 29 & $22,3 \%$ \\
\hline \multirow[t]{5}{*}{2} & Jenis Obat Panas yang & & \\
\hline & Diberikan & & \\
\hline & Parasetamol & 101 & $77,7 \%$ \\
\hline & Ibuprofen & 14 & $10,8 \%$ \\
\hline & Aspirin & 15 & $11,5 \%$ \\
\hline \multirow[t]{4}{*}{3} & Pengetahuan Efek & & \\
\hline & Samping Obat & & \\
\hline & $\mathrm{Ya}$ & 13 & $10 \%$ \\
\hline & Tidak & 117 & $90 \%$ \\
\hline \multirow[t]{7}{*}{4} & Sumber Informasi & & \\
\hline & Penggunaan Obat & & \\
\hline & $\begin{array}{c}\text { Apoteker/dokter/tenaga } \\
\text { kesehatan }\end{array}$ & 93 & $71,5 \%$ \\
\hline & Orangtua/teman/tetangga & 22 & $16,9 \%$ \\
\hline & Pengetahuan sendiri & 4 & $3 \%$ \\
\hline & Iklan & 10 & $7,7 \%$ \\
\hline & Kemasan & 1 & $0.8 \%$ \\
\hline \multirow[t]{9}{*}{5} & Dasar Pertimbangan & & \\
\hline & Pemilihan Obat & & \\
\hline & Khasiat & 26 & 20 \\
\hline & Harga & 2 & $1,5 \%$ \\
\hline & Iklan & 7 & $5,4 \%$ \\
\hline & Resep obat & 60 & $46,2 \%$ \\
\hline & Saran dari apoteker & 2 & $1,5 \%$ \\
\hline & Pengalaman pribadi & 2 & $1,5 \%$ \\
\hline & Rekomendasi orang lain & 31 & $23,8 \%$ \\
\hline
\end{tabular}

Pertimbangan pemilihan obat demam untuk anak oleh responden banyak didasarkan pada pengalaman menggunakan obat sesuai resep yang pernah dipakai sebelumnya dengan persentase sebesar $46,2 \%$, sedangkan jawaban lainnya lebih sedikit jumlahnya seperti khasiat $20 \%$, informasi/rekomendasi orang lain $23,8 \%$ berdasarkan harga $1,5 \%$ dan iklan $5,4 \%$. Hasil tersebut berbeda dengan penelitian sebelumnya yang menyebutkan bahwa sebanyak 34\% membeli obat tanpa resep karena pertimbangan dari apoteker, sebanyak $23 \%$ konsumen membeli obat tanpa resep berdasarkan pengalaman sebelumnya, sebanyak $15 \%$ konsumen memilih karena pertimbangan dari dokter, sebanyak $10 \%$ memilih membeli obat tanpa resep karena iklan dari TV, konsumen memilih obat tanpa resep karena informasi dari teman sebanyak 9\%, dan 9\% karena alasan lainlain (Candradewi et al., 2017).

Penggunaan antipiretik perlu diper-hatikan karena sesuai dengan himbauan WHO bahwa penggunaan antipiretik di negara berkembang tidak boleh diberikan secara rutin, kecuali dalam keadaan demam yang tinggi (Sweetman, 2019). United States Poison Control Center mencatat bahwa rata-rata 74.387 anak dibawah 6 tahun terpapar obat-obatan antipiretik, yaitu parasetamol, aspirin, dan ibuprofen. Tercatat lagi bahwa lebih dari 71.000 anak di Amerika Serikat dirawat karena mengalami overdosis antipiretik karena tertelan tanpa pengawasan dan kesalahan dalam terapeutik. Strategi pencegahan dapat dilakukan dengan membatasi jumlah obat dan penggunaan yang berlebihan, pengemasan dalam dosis yang aman untuk anak, dan pentingnya edukasi kepada orangtua mengenai obat-obatan antipiretik, penyimpanan, dan cara penggunaan yang benar. (Rakowsky et al., 2017).

\section{KESIMPULAN}

Berdasarkan hasil penelitian yang telah dilakukan maka dapat disimpulkan bahwa responden belum banyak yang mengetahui cara mengenali kondisi demam pada anak karena terbatasnya penggunaan termometer dan lebih banyak mengandalkan rabaan pada dahi sebagai cara mengidentifikasi demam. Terlebih lagi sepertiga responden tidak mengetahui penyebab demam pada anak. Selain itu, responden memilih melakukan tindakan swamedikasi dengan memberikan antipiretik khususnya parasetamol untuk setiap kondisi demam anak. Meskipun demikian, penggunaan parasetamol sebagian besar berdasarkan resep obat sebelumnya tanpa mengetahui efek samping yang mungkin timbul pada anak.

\section{DAFTAR PUSTAKA}

Aqeel, T, Shabbir, S, Basharat, H, Bukhori, M, Mobin, S, Shahid, H, Waqar, SA 2014, 'Prevalence of self-medication among urban and rural population of Islamabad, Pakistan', Tropical Journal of Pharmaceutical Research, 13, pp. 627-633

Ayu, EI, Irwanti, W, Mulyanti 2015, 'Kompres air hangat pada daerah aksila dan dahi terhadap penurunan suhu tubuh pada pasien demam di PKU Muhammadiyah Kutoarjo' Indonesian Journal of Nursing and Midwifery, 3(1), pp. 10-14. 
Barbi, E, Marzuillo, P, Neri, E, Naviglio, S, Krauss, BS 2017, 'Fever in children: pearls and pitfalls', Children, 4(81), pp. 1-19

Bebenista, MJ, Nowak, JZ 2014, 'Paracetamol: mechanism of action, applications, and safety concern', Acta Poloniae Pharmaceutica ñ Drug Research, 71(1), pp. 11-23.

Candradewi, SF, Kristina, SA 2017, 'Gambaran Pelaksanaan Swamedikasi dan Pendapat Konsumen Apotek Mengenai Konseling Obat Tanpa Resep di Wilayah Bantul', Pharmaciana, 7(1), pp. 41.

Crocetti, M, Moghbeli, N, Serwint, J 2001, 'Fever phobia revisited: have parental misconceptions about fever changed in 20 years?', American Academy of Pediatric, 107(6), pp. 1241-1246

El-Radhi, AS 2018, Clinical Manual of Fever in Children, Springer-Verlag, Berlin.

Fuadi, F, Bahtera, T, Wijayahadi, N 2010, 'Faktor risiko bangkitan kejang demam pada anak', Sari Pediatri, 12(3), pp. 142-149.

Gunduz, S, Usak, E, Koksal, T, Canbal, M 2016, 'Why fever phobia is still common?', Iranian Red Crescent Medical Journal, 18(8), pp. 1-6

Hay, AD, Costelloe, C, Redmond, NM, Montgomery, AA 2006, 'Antipyretic drugs for children', British Medical Journal, 333(775), pp. 4-5

Ikatan Dokter Anak Indonesia 2014, Kejang Demam: Tidak Seseram yang Dibayangkan (viewed 9 April 2020), http://www.idai.or.id/artikel/klinik/keluhananak/kejang-demam-tidak-seseram-yangdibayangkan

Ikatan Dokter Anak Indonesia 2014, Penanganan Demam Pada Anak (viewed 30 November 2019) http://www.idai.or.id/artikel/klinik/keluhananak/penanganan-demam-pada-anak

Kementerian Kesehatan Republik Indonesia 2018, Data dan Informasi Profil Kesehatan Indonesia. Kementerian Kesehatan RI, Jakarta.

Kristiyaningsih, A, Sagita, YD, Suryaningsih, I 2019, 'Hubungan tingkat pengetahuan ibu tentang demam denngan penanganan demam pada bayi 0-12 bulan di desa Datarajan wilayah kera puskesmas Ngarip Kabupaten Tanggamus Tahun 2018', Midwifery Journal, 4(1), pp. 26-31

Kurniati, HS 2016, 'Gambaran Pengetahuan Ibu Dan Metode Penanganan Demam Pada Balitia Di Wilayah Puskesmas Pisangan Kota Tangerang Selatan' Skripsi, Fakultas
Kedokteran dan Ilmu Kesehatan UIN Syarif Hidayatullah.

Leonis, MA, Alonso, EM, Im, K, Belle, SH, Squires, RH 2013, 'Chronic acetaminophen exposure in pediatric acute liver failure', Pediatrics, 131, pp. 740-746

Lubis, IND, Lubis, CP 2016, 'Penanganan demam pada anak', Sari Pediatri, 12(6), pp 409.

Mufaza, U 2009, 'Pengetahuan dan Perilaku Orangtua Dalam Pemberian Obat Penurun Panas Pada Anak Ditinjau dari Aspek Sosial Ekonomi' Skripsi, Fakultas Kedokteran Universitas Indonesia

Mutma'inah, UI 2019, Pemeriksaan Dasar, Penatalaksanaan, dan Edukasi Dokter Umum Tentang Demam pada Bayi dan Balita di Kecamatan Purwantoro, Kabupaten Wonogiri.

Rakowsky, S, Spiller, HA, Casavant, MJ 2017, 'Antipyretic medication exposures among young children reported to US poison centeres, 2000-2015', Clinical Pediatrics, 57(3), 266-276.

Riandita, A 2012, 'Hubungan Antara Tingkat Pengetahuan Ibu Tentang Demam Dengan Pengelolaan Demam Pada Anak' Skripsi, Fakultas Kedokteran Universitas Diponegoro.

Salgado, PO, Silva, LCR, Silva, PMA, Chianca, T.C.M. 2016. 'Physical methods for the treatment of fever in critically ill patients : a randomized controlled trial', Journal of School of Nursing USP, 50(5), pp. 823-830

Sari, RAP, Irawati, NAV 2018, 'Asosiasi penggunaan aspirin pada viral infection dengan sindrom reye', Majority, 7(3), pp. 266-270.

Shann, F 2013, Emergency Drug Doses, The Royal Children Hospital Melbourne, Melbourne.

Sodikin 2016, 'Perbandingan efektifitas pemberian kompres hangat dan tepidsponge terhadap penurunan suhu tubuh anak', Kesehatan Holistik, 10(1), pp. 36-44.

Soedibyo, Soepardi, Elsye, S 2016, 'Gambaran persepsi orang tua tentang penggunaan antipiretik sebagai obat demam', Sari Pediatri, 8(2), pp. 142.

Sostres, C, Gargallo, CJ, Lanas, A 2013, 'Nonsteroidal anti-inflammatory drugs and upper and lower gastrointestinal mucosal damage', Arthritis Research \& Therapy, 15(3), S3.

Sullivan, JE, Farrar, HC 2011, 'Fever and antipyretic use in children' Official Journal of The Pediatrics, 127, pp. 580-587. 
Surya, MANI, Artini, GA 2018, 'Pola penggunaan parasetamol atau ibuprofen sebagai obat antipiretik single therapy pada pasien anak', E-Jurnal Medika, 7(8), pp. 113

Sweetman, SC 2009, Martindale $36^{\text {th }}$ Edition. Pharmaceutical Press, London.

Urbane, UN, Likopa, Z, Gardovska, D, Pavare, J, Beliefs 2019, 'Practices and health care seeking behavior of parents regarding fever in children', Medicina Kaunas, 55(7), pp. 398.

Wardiyah, A, Setiawati, Setiawan, D 2016, 'Perbandingan efektifitas pemberian kompres hangat dan tepidsponge terhadap penurunan suhu tubuh anak yang mengalami demam RSUD. Dr. H. Moeloek Provinsi Lampung', Jurnal Ilmu Keperawatan, 4(1), pp. 44-56.

Wyckoff, AS 2009, 'Thermometer Use 101', AAP News, 30(11), pp. 29-29. 